\title{
Peran Ustadz dalam Meningkatkan Pemahaman Agama Islam Terhadap Mu'allaf di Markaz Dakwah
}

\author{
Karliana Indrawari ${ }^{1}$, Azwar Hadi ${ }^{2}$, Madi Apriadi ${ }^{3}$ \\ ${ }^{1}$ IAIN Curup, ${ }^{2}$ UM Palembang , ${ }^{3}$ UIN Raden Fatah Palembang \\ ${ }^{1}$ karlianaindrawari@gmail.com, ${ }^{2}$ azwarhadiump1971@gmail.com, \\ 3 madiapriadi@gmail.com
}

\begin{abstract}
This study aims to determine the history of the founder of the Da'wah Markaz; to know the progress from the year of establishment until now; to find out what methods used ustadz in learning. The research method used is the field study research method. Data collection techniques in this study using observation, interviews and documentation. Data analysis techniques using Miles and Huberman, namely data reduction, data presentation, and data conclusions. The results of the study are the city of Palembang is the place where the headquarters of Da'wah was established, because there is no conflict between religions or races. Education and development of learning delivered by the clerics in the propaganda markers as follows: Aqeedah and Morals, Fiqh of worship, Prophetic God, and Tilawatil or recitation of the Qur'an. As for the various teaching methods conducted by the cleric to convert Muslims to improve understanding of the Islamic religion are: lecture method, question and answer method, and method of giving assignments.
\end{abstract}

Keywords: role; ustdaz; religious understanding

\begin{abstract}
Abstrak
Penelitian ini bertujuan untuk mengetahui sejarah pendiri markaz dakwah; untuk mengetahui kemajuan dari tahun berdirinya sampai sekarang; untuk mengetahui metode apa yang digunakan ustadz dalam pembelajaran. Metode penelitian yang digunakan adalah metode studi lapangan. Penelitian ini menggunakan tekhnik wawancara, observasi dan dokumentasi.. Penelitian ini menganalisis data dengan cara mereduksi data, menyaji data dan menyimpulkan data. Hasil penelitian adalah kota palembang adalah tempat didirikannya markas dakwah, karena konflik antar agama atau ras tidak ada. Pendidikan dan pengembangan pembelajaran yang disampaikan oleh para ustad di markaz dakwah sebagai berikut:Aqidah dan Akhlak, Fiqh ibadah, Shiroh nabawi, dan Tilawatil atau pembacaan al-qur'an. Adapun macam-
\end{abstract}

FOKUS : Jurnal Kajian Keislaman dan Kemasyarakatan Vol. 5, No. 1, 2020

LPPM Institut Agama Islam Negeri (IAIN) Curup - Bengkulu

p-ISSN 2548-334X, e-ISSN 2548-3358

DOI: $10.29240 /$ jf.v5i1.1340 
macam metode mengajar yang di lakukan ustad terhadap muallaf untuk meningkatkan pemahaman keagamaanadalah:Metode pemberian tugas (resitasi), Metode ceramah, dan Metode tanya jawab.

Kata Kunci : peran; ustdaz; pemahaman keagamaan

\section{Pendahuluan}

Kebebasan manusia dalam kehidupan salah satunya adalah menganut suatu agama. Agama Kristen, islam, Hindu, Budha merupakan universal option, atau pilihan-pilihan universal, sehingga tidak beralasan orang-orang yang beragama hanya karena ikut-ikutan atau sekedar mengikuti para leluhur atau nenek moyangnya. Agama adalah sebuah keyakinan yang tidak mudah dipahami oleh manusia, melainkan dengan instink aatu naluri manusia itu sendiri. ${ }^{1}$

Realitas menunjukkan bahwa agama bukan milik kaum kelas bawah, tetapi sebaliknya milik semua lapisan masyarakat tanpa mengenal kelas masyarakatnya. Dalam Islam manusia diberi kebebasan dalam memilih yang terbaik sehingga memperoleh perubahan nasib manusia itu sendiri yang tertera dalam Al-Qur'an Surat Ar-Ra'd ayat 11 yang artinya "Bagi manusia ada malaikat-malaikat yang selalu mengikutinya bergiliran, di muka dan di belakangnya, mereka menjaganya atas perintah Allah. Sesungguhnya Allah tidak merobah keadaan sesuatu kaum sehingga mereka merubah keadaan yang ada pada diri mereka sendiri. Dan apabila Allah menghendaki keburukan terhadap sesuatu kaum, maka tak ada yang dapat menolaknya; dan sekalikali tak ada pelindung bagi mereka selain Dia".2

Dalam kehidupan manusia memiliki hak dalam beragama sebagai wujud kesadaran diri. Tidak ada satu pun orang boleh memaksakan agama kepada orang lain. Karena manusia melakukan peribadatan didasari atas keyakinan dan keikhlasan bukan karena keterpaksaan psikologis, materi maupun moral. ${ }^{3}$

${ }^{1}$ Wiwik Setiyani, "Konversi Agama: Studi tentang Faktor Pindah Agama dari Kristen ke Islam pada Masyarakat Kelas Menengah di Surabaya," dalam Antologi Kajian Islam, ed. Syaichul Hadi Purnomo (Surabaya: Pascasarjana IAIN Sunan Ampel Press, 2002), 50.

${ }^{2}$ Terjemahan al-Qur'an, 13 ( al-Ra'd): 11.

${ }^{3}$ Bambang Budiwiranto, "Studi tentang upaya dakwah Majlis Muhtadin dalam memelihara keimanan kaum muallaf (Nasrani-Islam) di kotamadya Yogyakarta," (Skripsi, IAIN Sunan Ampel Fakultas Dakwah, Surabaya, 1995), 1. 
Agama Islam merupakan agama dakwah baik dalam pemikiran dan praktek. Hal ini dapat kita lihat dalam ayat-ayat suci Al-Qur'an maupun dalam sejarah kehidupan Nabi Muhammad SAW, yang mencontohkan ajaran yang sama bahkan beliaulah yang memproklamasikan untuk pertama kalinya pada penduduk Jazirah Arabia pada abad ke-7 M. ${ }^{4}$

Fenomena yang sering terjadi di masyarakat saat ini adalah pindah agama yang disebabkan oleh perasaan kebimbangan dan keraguan dalam menghadapi persoalan kehidupan dunia. Ketidakpuasan atau ketidakmampuan seseorang dalam menyelesaikan problem kehidupan ini cenderung mencari alternatif atau solusi lain yang lebih memadai. Bentuk dan konsep alternatif ini sangat beragam, oleh karena itu sangat tergantung pada siapa atau apa yang mempengaruhi pola pikirnya. ${ }^{5}$

Keluar dari agama atau pindah agama pada umumnya disebabkan karena hilangnya kepercayaan diri seseorang terhadap suatu agama yang selama ini sangat diyakininya. Dimana agamanya tidak dapat memberikan ketenangan dan kedamaian jiwanya yang selama ini dianggap sebagai sandaran utama dalam mengisi kegiatan spiritual. Sehingga terjadi krisis atau stagnan pada diri seseorang. ${ }^{6}$

Max Muller membagi agama-agama besar yang ada di dunia ini dalam dua kategori yaitu agama dakwah dan agama non dakwah. Agama Islam, Kristen, dan Budha merupakan kategori agama dakwah, sedangkan agama Yahudi, Zoroaster, dan Brahma termasuk dalam kategori agama non dakwah. $^{7}$

Sebagai manusia wajib memahami dan memiliki prinsip-prinsip agama yang merupakan pedoman hidup yang harus diaplikasikan dalam kehidupan sehari-hari. ${ }^{8}$ Sehingga kita sebagai manusia wajib mempelajari agama Islam secara mendalam baik melalui lembaga atau orang yang memiliki pengetahuan tentang keislaman.Kurangnya informasi tentang Islam yang perlu disampaikan oleh narasumber, dapat menyebabkan salah persepsi, bahkan dapat menimbulkan antipati terhadap Islam Karena itu memilih

${ }^{4}$ Ibid., 2.

${ }^{5}$ Setiyani, “Konversi Agama, 51.

${ }^{6}$ Ibid., 51

${ }^{7}$ Thomas W Arnold, Sejarah Dakwah Islam: Terjemahan Nawawiie Rambe (Jakarta: Widjaya, 1985), 1.

${ }^{8}$ Budiwiranto, "Studi tentang upaya dakwah, 3. 
lembaga atau personil yang akan dijadikan sebagai nara sumber menjadi penting. ${ }^{9}$

Maka dari itu Markaz Dakwah bertujuan untuk membimbing para mu`allaf untuk meningkatkan pemahaman Agama Islam tentang Aqidah, Akhlak, Siroh Nabawi, dll dengan metode ceramah dan diskusi yang dibatasi pembelajarannya yaitu kurang lebih empat bulan dalam satu semester.

Markaz dakwah juga merupakan program kerja sama antara Muhammadiyah dan AMCF (Asia Muslim Charity Foundation) yang berupa program pendidikan intensif atau program yang di khususkan untuk kaum mu allaf yaitu dalam seminggu lima hari dan cara pembelajarannya pagi dan sore dan disusun kurikulumnya mulai dari Aqidah, Akhlak, Fiqh Ibadah dan cara membaca Al-Qur`an atau kajian tafsir dan hadits.Pada awal tahun 2014 berdirinya markaz dakwah di palembang merupakan ekspansi dari program yang di selenggarakan oleh AMCF (Asia Muslim Charity Foundation) di kota Makassar dan berhasil dalam perkembangan dakwahnya dan pada keberhasilan itu pula ada usulan untuk mendirikan dan membangun Markaz Dakwah di Indonesia bagian barat sebelumnya ada banyak opsi atau masukan untuk di Indonesia bagian barat yaitu ada dua kota medan dan palembang sedangkan di kota medan takutnya terjadi konflik antar agama dan suku (ras) dikarenakan dikota tersebut mayoritas masyarakatnya beragama non muslim sedangkan di kota palembang konflik antar agama atau ras bisa dikatakan tidak ada, maka dari itu terpilihlah di kota palembang karena di kota palembang aman dari konflik antar agama atau ras.

Markaz Dakwah awalnya ingin dinamakan mu`allaf center akan tetapi dengan kata "mu'allaf" tersebut sangat sensitif karena tidak ingin menyinggung perasaan masyarakat non muslim oleh karna itu dinamakan dengan Markaz Dakwah untuk pembinaan para mu`allaf, akan tetapi di Markaz Dakwah pembinaannya secara insentif ini berbeda dengan pembinaan mu`allaf yang biasa, pembinaan mu allaf insentif ini secara countinue atau terus menerus selama kurang lebih empat bulan pembinaan untuk memahami, mempelajari dan mendalami ajaran agama Islam 
Program di Markaz Dakwah sama halnya dengan program di ma`had sa`ad bin abi waqash. Akan tetapi program di ma`had sa`ad bin abi waqash mengarah kepada pendidikan sedangkan di markaz dakwah mengarah pada pembinaan para mu`allaf untuk memahami, mempelajari dan mendalami ajaran agama Islam

Akmal Mundiri dan Irma Zahra dengan judul penelitian adalah corak represebtasi identitas ustadz dalam proses transmisi pendidikan karakter di pesantren dalam jurnal Pendidikan Islam Indonesia Vol 2 No 1 2017. Hasil penelitian adalah Pesantren is as educational institution has Tafaqquh fi Aldin- oriented has been long known as an educational Institution whose main purpose form of moral. In the process of transmission can't be denied the role of ustadz in learning process, both in side and outside classroom. The process of transformation and modernization are all lines require the figure of ustadz in Pesantren to make accommodation, concessions for the transformation of education and learning system in pesantren. Pesantren is as part of the nation's community and also inseparable from the influences of ongoing National dynamics today. It is caught in a wave of globalization with all its positive and negative values. Similarly, ustadz of pesantren which also certainly, cannot be separated from the transformation so that there is a shift in identity representation in the form of mental or language representation.

Ahmad Marzuki dengan judul penelitian Dinamika Dan Peran Majlis Taklim Dalam Meningkatkan Pengetahuan Keagmaan Di Wilayah Suku Tengger dalam jurnal Mafhum Vol 1 No 2 2016. Hasil penelitian adalah Majelis ta'lim sebagai salah satu penyelenggara pendidikan Islam di wilayah Tengger khususnya di daerah kecamatan Tosari Kabupaten Pasuruan akhirakhir ini berkembang pesat. Hal ini tampak dari tempat ibadah yang juga dijadikan basis kegiatan pengetahuan keagamaan bagi umat Muslim yang tersebar di seluruh wilayah kecamatan Tosari Kabupaten Pasuruan. majelis ta' lim adalah lembaga pendidikan Islam non formal yang merupakan wadah untuk membina dan mengembangkan kehidupan beragama dalam rangka meningkatkan pengetahuan keagamaan.

Penelitian ini bertujuan untuk mengetahui sejarah pendiri markaz dakwah; untuk mengetahui kemajuan dari tahun berdirinya sampai sekarang; untuk mengetahui metode apa yang digunakan ustadz dalam pembelajaran. 
90 | FOKUS : Jurnal Kajian Keislaman dan Kemasyarakatan Vol. 5, No. 1, 2020

Metode penelitian yang digunakan adalah metode field study research. Tekhnik pengumpulan data dalam penelitian ini menggunakan observasi, wawancara dan dokumentasi. Tekhnik analisa data menggunakan Miles and Huberman yaitu reduksi data, penyajian data, dan kesimpulan data.

\section{Perkembangan Markaz Dakwah}

Dari awal mula berdirinya markaz dakwah perkembangannya sangat cukup signifikan meliputi penyebaran muallaf dari sabang sampai merauke masuk ke markaz dakwah untuk belajar, memahami, dan mengembangkan ilmu agama Islam

Sedangkan untuk perkembangannya dalam belajar, memahami dan mengembangkan ilmu agama dari awal berubah-ubah melihat kondisi dan keadaan muallaf dalam mengikuti usaha untuk memahami ilmu agama Islam Dikarenakan ada bebebrapa faktor-faktor yang menyebabkannya: (1) Faktor dan keadaan. (2) Faktor usia, (3) Faktor waktu di karenakan proses pembelajarannya sangat singkat.

\section{Pendidikan dan pembelajaran yang diberikan kepada muallaf}

Proses pendidikan dan pembelajaran muallaf di makaz dakwah sangat di butuhkan bagi para muallaf untuk belajar dan memahami ilmu agama yang di markaz dakwah, adapun pendidikan dan pengembangan pembelajaran yang di sampaikan oleh para ustad di markaz dakwah sebagai berikut:

Pertama.Aqidah dan Akhlak adalah cara yang dilakukan oleh seseorang secara terencana dan sadar dalam membentuk dan menyiapkan manusia dalam mengetahui, mengenal, menganalisis, menghayati dan mempercayai bahkan menerapkan dalam kehidupan sehari-hari berdasarkan al-quran dan hadits.Sedangkan tujuan pemberian pemahaman aqidah akhlak bagi muallaf adalah:(1) memupuk dan mengembangkan pengetahun, pengalaman, pembiasaan, serta memberikan pengalaman kepada muallaf bagaimana aqidah Islam sehingga menjadi muslim yang taat dan beriman kepada Allah SWT. Dan (2) mengaplikasikan akhlak yang mulia dan menghindari akhlak tercela baik dalam kehidupan individu maupun sosial, sehingga terwujud manusia muslim yang mulia. 
Kedua Fiqih. Didalam pembelajaran fiqih, para mu'allaf mempelajari tentang bagaimana cara bersuci yaitu wudhu, tayamum, mandi wajib, dan beristinjak dan bagai mana tatacara ibadah sholat baik sholat wajib maupun sholat sunnah dan bagai mana cara berpuasa dan hal-hal yang membatalkannya.

Ketiga Shiroh Nabawi atau sejarah kenabian. Muallaf mempelajari tentang sejarah-sejarah kenabian mulai dari nabi Adam AS sampai ke Nabi Muhammad SAW. Dan bagaimana cara dakwah para nabi dan apa saja mukjizat para Nabi dan Rasul.

Keempat Tilawatil atau cara pembacaan Al-Qur'an. Para muallaf di berikan bekal ilmu pengetahuan tentang bagaimana cara cepat untuk memahami dalam pembacaan Al-Qur'an karna di markaz dakwah di berikan kurun waktu yang sangat singkat yaitu kurang lebih empat bulan.

\section{Metode Belajar Mengajar Di Markaz Dakwah}

Adapun macam-macam metode mengajar yang di lakukan ustad terhadap muallaf untuk meningkatkan pemahaman agama Islam sebagai berikut:

Pertama Metode ceramah. Dalam metode ceramah, ustadz menyampaikan pengertian-pengertian materi pengajaran kepada muallaf pada saat di kelas dengan menggunakan lisan, dalam metode ceramah yang dberikan ustadz kepada muallaf terdapat kesatuan bahan pelajaran apa yang akan di sajikan kepada murid-murid, bagaimana mengajarnya dan alat-alat pengajaran apa yang di perlukan.Dalam penerapan metode ceramah, ustadz mempertimbangkan: (1) Dalam memberikan pelajaran supaya diadakan varisi, tanya jawab, audio visual, dan sebagainya. (2) Bahan pelajaran harus di sesuaikan dengan taraf kejiwaan anak didik, lingkungan sosial anak didik, serta lingkungan kebudayaan. (3)Bahasa, ucapan, tempo, dan tekananya.Sikap dan cara bediri guru sebagai penceramah harus menimbulkan perasaan simpatik. 


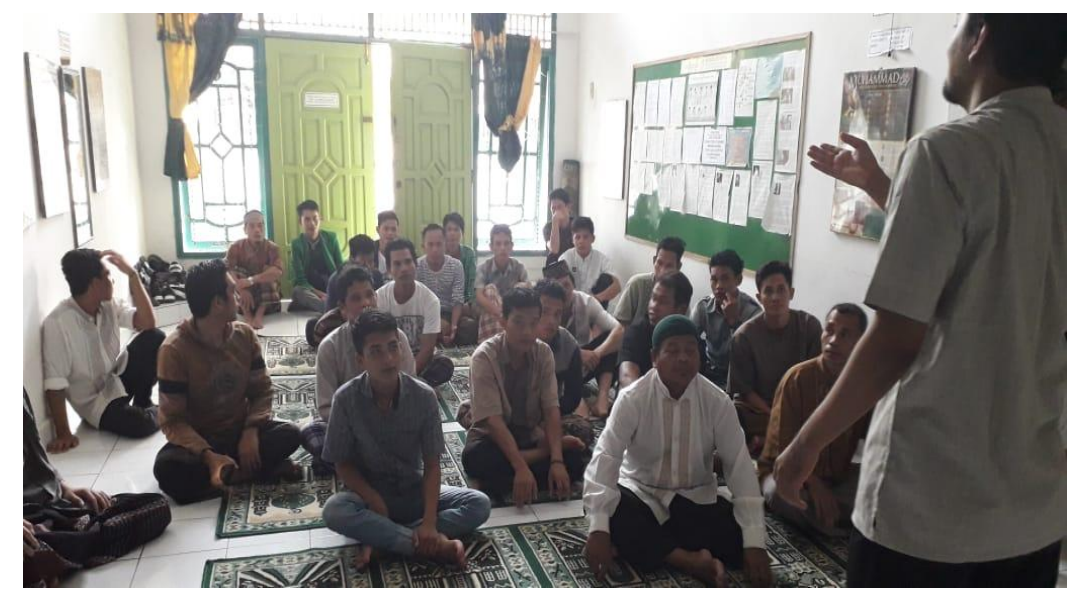

Gambar 1.1 metode ceramah

Kedua Metode tanya jawab. Metode tanya jawab yang dilakukan oleh ustadz dan muallaf tentang materi agama Islam. Metode tanya jawab ialah suatu metode dimana seorang ustad atau guru memberikan pertanyaan kepada siswa, kemudian siswa menjawab pertanyaan tentang materi yang telah mereka pahami, sehingga merangsang muallaf agar perhatian tercurahkan kepada masalah yang sedang dibicarakan dan Untuk mengerahkan proses berfikir.

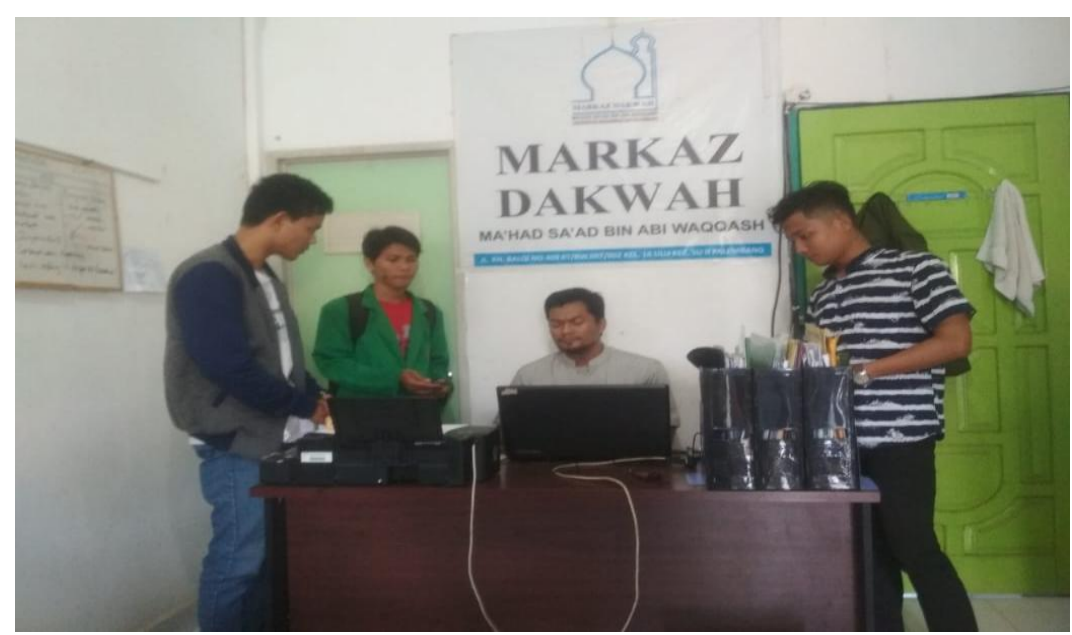

Gambar 1.2 metode tanya jawab

Ketiga Metode memberi tugas belajar (Resitasi)yaitu metode dalam pemberian tugas oleh seorang guru diluar jam pelajaran. Dalam penerapan di Markaz Dakwah, muallaf dapat mengerjakan tugasnya tidak hanya dirumah, tetapi dapat diperpustakaan, di kebun percobaan, di laboraturium, dan 
sebagainya. Tujuan metode resitasi untuk mengaktifkan muallafdalam memahami dan mempelajari masalah-masalah dengan membaca sendiri, mengerjakan sendiri, sehingga muallaf lebih rajin.

\section{Kesimpulan}

Pada awal tahun 2014 berdirinya markaz dakwah di palembang merupakan ekspansi dari program yang di selenggarakan oleh AMCF (Asia Muslim Charity Foundation) di kota Makassar dan berhasil dalam perkembangan dakwahnya dan pada keberhasilan itu pula ada usulan untuk mendirikan dan membangun Markaz Dakwah di Indonesia bagian barat sebelumnya ada banyak opsi atau masukan untuk di Indonesia bagian barat yaitu ada dua kota medan dan palembang sedangkan di kota medan takutnya terjadi konflik antar agama dan suku (ras) dikarenakan dikota tersebut mayoritas masyarakatnya beragama non muslim sedangkan di kota palembang konflik antar agama atau ras bisa dikatakan tidak ada, maka dari itu terpilihlah di kota palembang karena di kota palembang aman dari konflik antar agama atau ras.

Untuk perkembangannya dalam belajar, memahami dan mengembangkan ilmu agama dari awal berubah-ubah melihat kondisi dan keadaan muallaf dalam mengikuti usaha untuk mehami ilmu agama Islam Dikarenakan ada bebebrapa faktor-faktor yang menyebabkannya:Faktor dan keadaan, Faktor usia, dan Faktor waktu di karenakan proses pembelajarannya sangat singkat

Proses pendidikan dan pembelajaran muallaf di makaz dakwah sangat di butuhkan bagi para muallaf untuk belajar dan memahami ilmu agama yang di markaz dakwah, adapun pendidikan dan pengembangan pembelajaran yang di sampaikan oleh para ustad di markaz dakwah sebagai berikut: Aqidah dan Akhlak, Fiqh ibadah, Shiroh nabawi, dan Tilawatil atau pembacaan al-qur'an

Adapun macam-macam metode mengajar yang di lakukan ustad terhadap muallaf untuk meningkatkan pemahaman agama islam sebagai berikut:Metode ceramah, Metode tanya jawab, dan Metode pemberian tugas (resitasi) 
94 | FOKUS : Jurnal Kajian Keislaman dan Kemasyarakatan Vol. 5, No. 1, 2020

\section{Daftar Pustaka}

Ahmad Abu dan Prasetya Tri Joko. 1997. Strategi Belajar Mengajar. CV Bandung: Pustaka Setia.

Ahmad Abu dan Soleh Munawwar. 2005. Psikologi Perkembangan. Jakarta: Rineka Cipta.

Djali. 2008. Psikologi Pendidikan. Jakarta: Bumi Aksara.

Mundiri, Akmal dan Irma Zahra. 2017. corak represebtasi identitas ustadz dalam proses transmisi pendidikan karakter di pesantren. Jurnal Pendidikan Islam Indonesia Vol 2 No 12017

Marzuki, Ahmad. 2016.dinamika dan peran majlis taklim dalam meningkatkan pengetahuan keagmaan di wilayah suku Tengger. jurnal Mafhum Vol 1 No 22016

Salam Burhanuddin.2000. Pengantar Filsafat.Jakarta: PT Bumiaksara.

Http//www. Pengelolaan Pengajaran. Com 